\title{
Development of the Bankruptcy Institution in Russia: Features of Procedural and Legal Regulation
}

\author{
G.E. Ageeva, ${ }^{1, *}$ and P.P. Lang ${ }^{1}$ \\ *Corresponding author: galinaageevva@mail.ru \\ ${ }^{1}$ Samara State University of Economics, Samara, Russia
}

\begin{abstract}
The study of the development of bankruptcy institution procedural and legal regulation is very pressing in modern society, since the number of insolvent subjects is increasing every year, which inevitably increases the use of the norms of the institution being studied. However, in law enforcement practice, a number of problems arise due to the lack of a unified theoretical-based approach in constructing the legal regulation of the bankruptcy institution. The purpose of this study is to analyze the features of the procedural and legal regulation of the bankruptcy institution. The objectives of the study are to examine the system of legislation governing the bankruptcy institution, to analyze the law enforcement practice of declaring debtors insolvent, identifying problems of procedural regulation and the formulation of proposals for their elimination. In carrying out the study as the main method of knowledge, the authors relied on the materialist dialectic. In addition, other research methods were used: analysis and synthesis; induction, deduction; comparative law, etc. Abstracting from specific criteria and categorical problems, the study examined general provisions, concepts and categories of the institution of insolvency (bankruptcy), features of its procedural and legal regulation, as well as identified its problems. Due to a comprehensive and consistent analysis in accordance with the purpose and objectives of the study, which are its stages, it was possible to come to some conclusions and formulate certain recommendations. The significance of the study has both a theoretical aspect and an applied one: the formed theoretical concept of the institution of bankruptcy can enrich legal science, and proposals designed to solve existing lawenforcement problems can be used in the implementation of the norms of the institution under study.
\end{abstract}

Keywords: bankruptcy, insolvency, non-solvency, to declare bankrupt, special proceedings.

\section{Introduction}

Features of inquiry on the cases of the studied type of procedure, are established by ch. 28 of the Arbitration Procedure Code of the Russian Federation of 24.07.2002 No. 95-FZ [1] and other federal laws regulating the issues of insolvency (bankruptcy).

The purpose of the insolvency (bankruptcy) institution in Russia are formulated by the legislator as the objectives of particular procedures applied in a bankruptcy case. Thus, according to Article 2 of the Federal Law "On Insolvency (Bankruptcy)" of 26.10.2002 No. 127-FZ [2], financial rehabilitation is a procedure applied in a bankruptcy case against a debtor in order to restore its solvency and repay the debt in accordance with the debt repayment schedule; external management - a procedure applied in a bankruptcy case against a debtor in order to restore its solvency; bankruptcy proceedings - a procedure applied in a bankruptcy case against a debtor recognized as bankrupt in order to adequately satisfy the claims of creditors; observation is a procedure applied in a bankruptcy case against a debtor in order to safeguard its property, analyze the debtor's financial condition, draw up a register of creditors' claims and hold a first meeting of creditors, settlement agreement is a procedure applied in a bankruptcy case at any stage of its consideration in to terminate bankruptcy proceedings by reaching an agreement between the debtor and the creditors.

An innovation in the examining institution is the establishment of new procedures applied in the bankruptcy cases of individuals, including procedures for restructuring citizen's debts and selling citizen's property. The first procedure is of a rehabilitation nature and is used to restore the debtor's solvency and pay off debts to creditors in accordance with the debt restructuring plan. The purpose of the second procedure is to adequately meet the claims of an individual's creditors.

\section{Problem Statement}

The legal regulation of the public law institution under study is distinguished by its dynamic: changes and additions are constantly made to bankruptcy legislation. In our opinion, it indicates the absence of a clear, unified approach to understanding this institution [3].

We tend to suppose that the institution of bankruptcy is a system of rules governing special proceedings, considered and resolved in the framework of arbitration proceedings. The studied type of special procedure, an assize to declare a debtor insolvent (bankrupt), consists of a set of reciprocal, sequential procedures (or stages) aimed at achieving a predetermined, rightly significant result - confirmation of the fact of insolvency of a subject with all the ensuing 
consequences. Taking this position into account, it is necessary to study the peculiarities of the procedural and legal regulation of the institution under study, identify weaknesses of its regulation and suggest ways to eliminate them.

\section{Research Questions}

Today, not only enterprises, but also individuals can declare themselves bankrupt. Insolvency (bankruptcy) proceedings for individuals are becoming increasingly popular due to the fact that in foreign countries thousands of people declare themselves bankrupt. A certain role, with regards to Russia, was played in this by the fact that loans to individuals were actively issued in 2008 . The negative consequence of this phenomenon was the increase in overdue payables. The regulations on the bankruptcy of individuals have been in effect in Russia since October 2015, and the implementation of the latter in life causes a number of questions and discussion problems in law enforcement practice. The solution of such problems and issues is due to scientific research in the subject matter. First of all, there is an acute question about the refusal of arbitration managers to conduct insolvency (bankruptcy) procedures for citizens for the remuneration established by law. Also, when applying to the arbitration court with statements about the insolvency (bankruptcy) of citizens, it is apparent that the claimant-debtors of individuals are not aware of the procedural and regulatory requirements for filing such statements established by law. That in turn gives rise to objective obstacles to a timely trial on the insolvency of a citizen with the corresponding negative consequences, which in turn contradicts the goals and objectives of the insolvency institution (bankruptcy).

\section{Purpose of the Study}

Bankruptcy has certain problems and negative consequences not only with the bankruptcy of individuals, but also with the bankruptcy of corporate bodies. As is known, the bankruptcy law is intended, above all, to sift out inefficient and insolvent enterprises. However, small and medium enterprises often fall victim to such radical method as liquidation of an organization. According to statistics, not a single large enterprise with numerous debts has gone bankrupt today. Losing small and medium-sized enterprises, the state loses taxpayers, and also increases the unemployment rate due to the closure of a large number of enterprises. Accordingly, the state should, above all, help such organizations to avoid bankruptcy and to continue further successful economic and other commercial activities. In law enforcement practice there are, among other things, positive examples, when, having entered the bankruptcy procedure, the organization restored its activity. Thus, if in each situation arising through no fault of the debtor, a bankruptcy procedure was adequately carried out with the true goal of saving the plight of the enterprise and putting it on the true path of advance, the institution of bankruptcy in Russia would have a completely different content.

\section{Research Methods}

The main method of cognition relied on in this study is the materialist dialectic. In addition, other research methods were used: analysis and synthesis; induction, deduction; comparative law and others. Abstracting from specific signs and industry-specific problems, the study examined general provisions, concepts and categories of the institution of insolvency (bankruptcy), features of its procedural and legal regulation, as well as identified its problems.

\section{Findings}

As global experience shows that without adequate legislation governing insolvency (bankruptcy), among other aspects, a market economy cannot function effectively. The development of the bankruptcy institution in Russia lasted for quite a long time, since the provisions regarding bankruptcy were already noticed in Russian Pravda, which was one of the legislative acts in the eleventh and twelfth centuries. The considered institute also actively functioned during the reign of the Russian Empire. Considering fundamental changes that occurred in our country after 1917, taking into account the specifics of the socialist structure of the state, the institution of insolvency (bankruptcy) was not required. As for the legislation of the Russian Federation, the institution of bankruptcy received its legal consolidation in the Law of the Russian Federation of November 19, 1992 No. 3929-1 "On Insolvency (Bankruptcy) of Enterprises". Yet in view of the fact that in law enforcement practice there were no conditions for the adequate use of the provisions of this law, there was an obvious need for further reform of the regulatory framework for bankruptcy issues which in turn led to the creation of the Russian legal system, which takes both its own experience and the experience of foreign countries into account in the law "On the insolvency (bankruptcy) of enterprises" of 1998. However, further reform mainly took into account the interests of creditors, which had a negative effect on enterprises already ravaged. Accordingly, the conflicts that arose necessitated the adoption of a new law "On insolvency (bankruptcy)" of 2002, which has taken into account both the interests of the debtor and the interests of the creditor. First of all, this is reflected in the appearance of a new bankruptcy procedure - a procedure for the financial recovery of the debtor. It is the current law that provides for 
bankruptcy procedures that help to restore the debtor's solvency in a special legal regime: pre-trial reorganization, monitoring, financial rehabilitation, external management, settlement agreement, in the case of a citizen's bankruptcy debt restructuring procedure.

The insolvency (bankruptcy) institute was re-established in Russia in the period of the formation and development of a market economy to ensure the economic security of economic entities, from the unfair behavior of some participants in turnover, expressed in non-fulfillment of their obligations. Problems in the legal regulation of relations of insolvency (bankruptcy), in different interpretations of the considered norms of law in judicial practice cause the vulnerability of participants in civil legal relations.

The objectives of the bankruptcy institution procedures as outlined by the legislator and indicated by one as the objectives of individual procedures applied in a bankruptcy case, including restoring the debtor's solvency, adequate satisfaction of creditors' claims, etc., can be reduced to one common goal that is to insure balance of parties' interests in the case of debtor's insolvency (bankruptcy).

This legal position is also reflected in the Resolution of the Constitutional Court of the Russian Federation "On the case of verifying the constitutionality of the paragraph of the eighth paragraph 1 of article 20 of the Federal Law" On Insolvency (Bankruptcy) "in connection with the complaint of citizen A.G. Mezhentsev "dated 12.19.2005 N 12-P [4], in which the court indicated, due to the different, often diametrically opposite interests of the parties participating in the bankruptcy case, the legislator must guarantee the balance of their rights and legitimate interests, which, in fact, is publicly the legal purpose of the institution of bankruptcy.

The institution of bankruptcy distinguishes, as we have already mentioned, a type of special proceeding in the arbitration process. The considered type of legal proceedings is characterized by a combination of elements of the judicial (jurisdictional) and positive processes.

An example of extrajudicial insolvency (bankruptcy) proceedings is the procedure for convening and holding a meeting of debtor's creditors and them making decisions determining subsequent judicial activities in the entire insolvency (bankruptcy) case, in particular on introducing financial rehabilitation, external management, on changing the date of the procedure and other matters referred by the legislator to the exclusive competence of the meeting of creditors of the debtor.

Other examples of the non-jurisdictional insolvency (bankruptcy) process can be measures to restore the debtor's solvency, sale of the debtor's property, restructuring debtor's assets, and much more.

\section{Conclusion}

Despite the difficulties arising during the bankruptcy procedure, the prospect of the development of the analyzed institution still exists. First of all, the bankruptcy procedure should be simplified to the greatest extent. Given that it is expensive, it is necessary to reduce the cost of state duty and other mandatory payments. It is also necessary to introduce counseling centers that would assist in early prediction of bankruptcy. It is necessary to introduce measures that would allow more thoroughly checking the debtors for fictitious and deliberate bankruptcy, and in the event of the indicated signs, apply the criminal law measures to the guilty persons.

Also, in order to limit the amount of liquidated enterprises due to insufficient literacy of arbitration managers, the requirements for this profession should be tightened. Perhaps, in terms of an increase in educational qualifications, or a solution could be the presence of a compulsory license to carry out such activities, subject to passing certain control of knowledge and other necessary qualities.

A positive point is the fact that since the recognition of a citizen as bankrupt, a list of property that cannot be withdrawn under any circumstances is established.

Such a list is enshrined in Article 446 of the Civil Procedure Code of the Russian Federation and it contains the following:

1) residential premises, together with the land plot, in the event it is not the subject of a pledge in mortgage lending, and if it is the only one suitable for permanent residence;

2) ordinary household items and personal items;

3) property necessary for the professional activities of a debtor citizen, with the exception of property whose value exceeds one hundred minimum wages;

4) seeds necessary for the next sowing;

5) products and cash in an amount not less than the established minimum subsistence level;

6) fuel necessary for cooking and heating the premises to the debtor and his family;

7) means of transport and other necessary property in connection with his disability;

8) prizes, state awards and other honorary insignia awarded by a debtor citizen.

The application of this norm of law in the bankruptcy of an individual ensures compliance with the constitutional guarantees to citizens of the Russian Federation that is a socially responsible state.

The improvement of the insolvency (bankruptcy) law should, above all, balance between the interests of the debtor, creditor and arbitration manager, so as not to create an advantage in favor of any of them. This will not only reduce the amount of abuse of the right in this area, but also increase the number of organizations that have restored their solvency.

With enviable regularity, the legislation governing insolvency (bankruptcy) is subject to change to the legislator. So, in early 2018, amendments were made to the effect that it was necessary to disclose their intentions to go to court to 
declare the debtor bankrupt not only to the bankruptcy creditor, but also to the former employee and the debtor himself. This made it possible to increase the availability of information on the possible bankruptcy of the organization for potential counterparties of the debtor. Now it is possible to check through an open source financial partner, and to conclude whether it is necessary to enter into contracts with this person (the alleged bankruptcy). Such an arrangement hinders the increase in the payables of the future bankrupt.

In our opinion, for a short period of time the existence of the institution of bankruptcy in modern Russia, the latter had a great influence on the development of the domestic economy as a whole. The considered legal institute plays the role of a kind of "medic" of economic legal relations. Despite the fact that the creation of the institution of bankruptcy determines manifestations of abuse of the right by unscrupulous participants in these legal relations, the positive impulse of the institution in question is not amenable to revaluation. In our opinion, the improvement of the economics and the intensification of civil turnover in Russia to the greatest extent depend on the correct application of this legal institution.

\section{References}

1. Arbitration Procedure Code of the Russian Federation of 24.07.2002 No. 95-FZ. Retrieved from: http://www.consultant.ru/document/cons_doc_LAW_37800/. Accessed: 27.12.2018 (2002). [in Rus.].

2. Federal Law "On Insolvency (Bankruptcy)" of 26.10.2002 No. 127-FZ. Retrieved from: http://www.consultant.ru/document/cons_doc_LAW_39331/. Accessed: 27.12.2018 (2002). [in Rus.].

3. P.P. Lang, Osoboe proizvodstvo v arbitrazhnom processe: Teoreticheskie i prakticheskie aspekty. Samara: NOANO VPO SIBiU (2014). [in Rus.].

4. Resolution of the Constitutional Court of the Russian Federation "On the case of verifying the constitutionality of the paragraph of the eighth paragraph 1 of article 20 of the Federal Law" On Insolvency (Bankruptcy) "in connection with the complaint of citizen A.G. Mezhentsev" dated 12.19.2005 N 12-P. Retrieved from: http://www.consultant.ru/document/cons_doc_LAW_57463/. Accessed: 27.12.2018 (2005). [in Rus.]. 